\title{
МАТЕМАТИЧНА МОДЕЛЬ ДЛЯ ПРОГНОЗУВАННЯ ЕФЕКТИВНОСТІ РОЗУМОВОЇ ПРАЦІ ПРИ МЕТЕОПАТИЧНИХ РЕАКЦІЯХ
}

\section{Н. М. Волкова}

\author{
Тернопільський державний медичний університет ім. І.Я.Горбачевського
}

\begin{abstract}
У статті запропонована математична модель для прогнозування ефективності розумової праці у практично здорових осіб та виявлення їх відхилення у разі розвитку метеопатичної реакції за рівнем нейротизму у балах і функціональними показниками автономної регуляції серцевого ритму.
\end{abstract}

Ключові слова: математична модель, метеопатичні реакції, багатофакторний регресійний аналіз.

\section{МАТЕМАТИЧЕСКАЯ МОДЕЛЬ ДЛЯ ПРОГНОЗИРОВАНИЯ ЭФФЕКТИВНОСТИ УМСТВЕННОГО ТРУДА ПРИ МЕТЕОПАТИЧЕСКИХ РЕАКЦИЯХ}

\section{Н. М. Волкова}

\author{
Тернопольский государственный медицинский университет им. И. Я. Горбачевского
}

В статье предложена математическая модель для прогнозирования эффективности умственного труда у практически здоровых лиц и выявления их отклонений в случае развития метеопатических реакций по уровню нейротизма в баллах и функциональным показателям автономной регуляции сердечного ритма.

Ключевые слова: математическая модель, метеопатические реакции, многофакторный регрессионный анализ.

\section{MATHEMATICAL MODEL FOR PREDICTING PERFORMANCE OF MENTAL WORK IN UNFAVORABLE WEATHER EFFECTS}

\author{
Ternopil State Medical University by I. Ya. Horbachevsky
}

\begin{abstract}
The article proposes a mathematical model to predict the effectiveness of mental work in healthy persons and detection of rejection in the case of reaction in terms of unfavorable weather effects in points and functional parameters of autonomic regulation of heart rate.
\end{abstract}

Key words: mathematical model, unfavorable weather effects multifactorial regression analysis.

Вступ. Одним із актуальних завдань профілактичної медицини є своєчасне виявлення відхилень у стані здоров'я населення. Цього можна домогтися за допомогою створення математичних моделей дизадаптивних процесів в організмі людини. Одним із таких процесів є метеопатичні реакції в організмі практично здорової людини. Метеофактори є постійно діючим чинником зовнішнього середовища і створюють додаткові умови для напруження регуляторних систем організму у разі їх несприятливого впливу.

Нами виявлено [1], що за несприятливих метеоумов централізація автономного контролю функції кровообігу була необхідною умовою виконання тестового психоемоційного навантаження. Проведені нами обстеження практично здорових молодих осіб з високим рівнем нейротизму виявили суттєві особливості узгодження показників автономної регуляції і психоемоційного стану при різних типах погоди. Найчастіше виявляли середню обернену кореляцію швидкості опрацювання інформації у тестовому завданні з варіаційним розмахом тривалості кардіоциклів. Отже централізація автономного контролю функції кровообігу була необхідною умовою виконання тестового психоемоційного навантаження в усіх групах обстежених.

У осіб з високим нейротизмом мобілізація центральних механізмів автономної регуляції при виконанні психоемоційного навантаження спрацьовувала із запізненням. Тому вважали за доцільне створення математичної моделі, яка б допомогла спрогнозувати імовірні метеопатичні зміни в організмі людини. Для 
цього проаналізували функціональний стан практично здорових осіб з низьким нейротизмом, які менш схильні до метеопатичних реакцій.

Матеріали і методи досліджень. У практично здорових осіб віком 19-20 років з низьким нейротизмом за Г. Айзенком [2] досліджували взаємозв'язок між показниками автономної регуляції у вихідному стані, при виконанні тестового психоемоційного навантаження, протягом періоду відновлення і рівнем нейротизму, екстраверсії, розумової працездатності, індексом реактивності при метеоситуації I і III типів.

Кардіоінтервалограми аналізували у програмі Ехеї за методом варіаційної пульсометрії [3]. Для статистичної обробки брали масиви по 100 кардіоінтервалів, зареєстрованих у вихідному стані, на початку тестового навантаження, на початку і в кінці періоду відновлення. Обраховували для кожного обстеженого середнє значення тривалості крдіоциклу М, с; т - стандартне відхилення; БХ, с; Мо, с; АМо, \%; індекс напруження (IH) в ум. од. як співвідношення амплітуди моди до подвоєного добутку моди і варіаційного розмаху тривалості кардіоциклів у вибірці; вегетативний показник ритму (ВПР) в ум. од. як частку від одиниці до добутку моди і варіаційного розмаху тривалості кардіоциклів у вибірці. Обраховували середні значення отриманих показників, похибку середнього, середнє квадратичне відхилення [3, 4]. Кореляційний і багатофакторний регресійний аналіз здійснили у програмі Statgrafics із визначенням коефіцієнтів кореляції (г), показника достовірності (р). Об'єм вибірки у кожній групі обстежених дорівнював 22. Коефіцієнт реактивності визначали як відношення IН при циклоні до IН при антициклоні. Виділяють нормальну реактивність автономної системи (нормотонічний тип реактивності) при $<$ KP $<3$, гіперреактивність (гіперсимпатикотонічний тип реактивності автономної системи) при КР>3, гіпореактивність (асимпатикотонічний тип реактивності) при КР $<1$ [5].

Основна частина. Слід зауважити, що у осіб з низьким нейротизмом при несприятливій метеоситуації показник нейротизму мав суттєвий зв 'язок з показниками функціонального стану обстежених в усіх аналізованих вибірках. Так, при аналізі функціонального стану до навантаження отримано модель множинної регресії, де найсуттєвіший зв'язок спостерігався зі швидкістю опрацювання інформації. Рівняння (1) характеризує 97,27 \% мінливості показника $(\mathrm{p}<0,05)$ :

$$
\begin{aligned}
& Y=-107,861+140,32 X_{1}+76,1154 X_{2}-65,1154 X_{3}+ \\
& 0,979652 X_{4}-0,390625 X_{5}+12,4866 X_{6}+0,139248 X_{7}- \\
& 2,57133 X_{8}-1,35825 X_{9}+0,841054 X_{10}
\end{aligned}
$$

де Y - нейротизм у балах;

$\mathrm{X}_{1}$ - середня тривалість кардіоциклу;

$\mathrm{X}_{2}$ - варіаційний розмах тривалості кардіоциклів;

$\mathrm{X}_{3}$ - мода розподілу тривалості кардіоциклів;

$\mathrm{X}_{4}$ - амплітуда моди розподілу тривалості кардіоциклів;

$\mathrm{X}_{5}$ - індекс напруження;

$\mathrm{X}_{6}$ - вегетативний показник ритму;

$\mathrm{X}_{7}$ - кількість опрацьованих знаків за хвилину;

$\mathrm{X}_{8}$ - кількість помилок при виконанні тестового завдання;

$\mathrm{X}_{9}$ - коефіцієнт розумової працездатності;

$\mathrm{X}_{10}$ - індекс реактивності.

Функціональному стану під час виконання навантаження відповідає модель множинної регресії (2), яка охоплює 93,90 \% мінливості показника нейротизму із найбільш вагомим впливом варіаційного розмаху тривалості кардіоциклів $(\mathrm{p}<0,05)$ :

$$
\begin{aligned}
& Y=-21,6869+19,6674 X_{1}+79,6121 X_{2}-10,4626 X_{3}+ \\
& 0,149084 X_{4}-0,0201212 X_{5}+1,22877 X_{6}+0,0121871 X_{7} \\
& +0,103998 X_{8}-0,271544 X_{9}-1,2756 X_{10}
\end{aligned}
$$

де Y - нейротизм у балах;

$\mathrm{X}_{1}$ - середня тривалість кардіоциклу;

$\mathrm{X}_{2}$ - варіаційний розмах тривалості кардіоциклів;

$\mathrm{X}_{3}$ - мода розподілу тривалості кардіоциклів;

$\mathrm{X}_{4}$ - амплітуда моди розподілу тривалості кардіоциклів;

$\mathrm{X}_{5}$ - індекс напруження;

$\mathrm{X}_{6}$ - вегетативний показник ритму;

$\mathrm{X}_{7}$ - кількість опрацьованих знаків за хвилину;

$\mathrm{X}_{8}$ - кількість помилок при виконанні тестового завдання;

$\mathrm{X}_{9}$ - коефіцієнт розумової працездатності;

$\mathrm{X}_{10}$ - індекс реактивності.

На початку періоду відновлення функціональний стан обстежених характеризується за допомогою моделі множинної регресії (3), яка охоплює 84,87 \% мінливості рівня нейротизму у вибірці. Найсуттєвіший вплив мали варіаційний розмах тривалості кардіоциклів, швидкість опрацювання інформації та індекс реактивності, що відображено у рівнянні $(\mathrm{p}<0,05)$ :

$\mathrm{Y}=8,40382+31,5182 \mathrm{X}_{1}-4,91332 \mathrm{X}_{2}-31,5344 \mathrm{X}_{3}-$ $0,060289 X_{4}+0,00285726 X_{5}-0,112521 X_{6}+0,0611393 X_{7}$ $-0,494115 X_{8}-0,282262 X_{9}+3,93573 X_{10}$.

де Y - нейротизм у балах;

$\mathrm{X}_{1}$ - середня тривалість кардіоциклу;

$\mathrm{X}_{2}$ - варіаційний розмах тривалості кардіоциклів;

$\mathrm{X}_{3}$ - мода розподілу тривалості кардіоциклів;

$\mathrm{X}_{4}$ - амплітуда моди розподілу тривалості кардіоциклів; 
$\mathrm{X}_{5}$ - індекс напруження;

$\mathrm{X}_{6}$ - вегетативний показник ритму;

$\mathrm{X}_{7}$ - кількість опрацьованих знаків за хвилину;

$\mathrm{X}_{8}$ - кількість помилок при виконанні тестового завдання;

$\mathrm{X}_{9}$ - коефіцієнт розумової працездатності;

$\mathrm{X}_{10}$ - індекс реактивності.

Модель взаємозв'язку рівня нейротизму з функціональним станом обстежених наприкінці періоду відновлення охоплює 90,69 \% мінливості показника. Найсуттєвішим $(\mathrm{p}<0,05)$ є вплив середньої тривалості кардіоциклів, моди їх розподілу і швидкості опрацювання інформації під час тестового навантаження, що відображено у рівнянні (4):

$$
\begin{aligned}
& Y=11,4524+85,4331 X_{1}-11,1535 X_{2}-84,1787 X_{3}+ \\
& 0,230545 X_{4}-0,103027 * x 7+1,28937 X_{5}+1,28937 X_{6}+ \\
& 0,0914377 X_{7}-0,930391 X_{8}-0,558447 X_{Q}- \\
& -0,786409 X_{10},
\end{aligned}
$$

де Y - нейротизм у балах;

$\mathrm{X}_{1}$ - середня тривалість кардіоциклу;

$\mathrm{X}_{2}$ - варіаційний розмах тривалості кардіоциклів;

$\mathrm{X}_{3}$ - мода розподілу тривалості кардіоциклів;

$\mathrm{X}_{4}$ - амплітуда моди розподілу тривалості кардіоциклів;

$\mathrm{X}_{5}$ - індекс напруження;

$\mathrm{X}_{6}$ - вегетативний показник ритму;

$\mathrm{X}_{7}$ - кількість опрацьованих знаків за хвилину;

$\mathrm{X}_{9}$ - коефіцієнт розумової працездатності;

$\mathrm{X}_{10}$ - індекс реактивності.

\section{Лiтература}

1. Волкова Н. М. Особливості автономної регуляції виконання психоемоційного навантаження за несприятливих метеоумов / Н. М. Волкова // Буковинський медичний вісник. - 2009. - Т. 13, № 2. - С. 16-18.

2. Практическая психодиагностика. Методики и тесты. Издательский Дом "Бахрах": Самара, 1999. - 669 с.

3. Баевский Р. М. Оценка адаптационных возможностей организма и риск развития заболеваний / Баевский Р. М.,
Таким чином, фактор нейротизму має суттєвий зв'язок із реактивністю автономної регуляції кровообігу, ефективністю опрацювання інформації при виконанні психоемоційного навантаження і може застосовуватись для виявлення осіб із певним типом реагування. Фактор екстраверсії характеризує адаптивні можливості організму менш достовірно, ніж нейротизм.

Найчастіше виявляли середню обернену кореляцію швидкості опрацювання інформації у тестовому завданні з варіаційним розмахом тривалості кардіоциклів. Отже, централізація автономного контролю функції кровообігу була необхідною умовою виконання тестового психоемоційного навантаження в усіх групах обстежених.

Висновки. У осіб з низьким нейротизмом кореляційні зв'язки між функціональними показниками були значнішими і достовірнішими, ніж у обстежених з високим нейротизмом. При несприятливій погоді у осіб з низьким нейротизмом кореляційні зв'язки між функціональними показниками значно посилювалися, особливо у вихідному стані і протягом виконання психоемоційного навантаження. Це явище можна розглядати як прояв синхронізації регуляторних інтегративних впливів центральної нервової системи.

Запропонована математична модель дозволяє спрогнозувати, знаючи рівень нейротизму у балах, функціональні показники автономної регуляції серцевого циклу, ефективність розумової праці у практично здорових осіб та виявити їх відхилення у разі розвитку метеопатичної реакції.

Берсенева А. П. - М. : Медицина. - 1997. - 265 с.

4. Фокин В. Ф. Динамическая функциональная асимметрия как отражение функциональных состояний / В. Ф. Фокин // Журнал "Асимметрия". - 2007. - Т. 1, № 1. - С. 4-9.

5. Войнов В. Б. Методы оценки состояния систем кислородообеспечения организма человека / Войнов В. Б., Воронова Н. В., Золотухин В. В. ; под редакцией Г. А. Кураева. Ростов-на-Дону, 2002. - 99 с. 